\title{
"You kill the dam, you are killing a part of me": Dam removal and the environmental politics of river restoration
}

\begin{abstract}
River restoration through dam removal provides an opportunity to investigate the changing nature of environmental conflicts and politics in long-humanized landscapes. In New England, where over 14,000 dams fragment the region's rivers, dam removals are often highly contested. This is due, in part, to how the intertwined roles of history, identity, and aesthetics coalesce to create attachment to place and inspire the defense of dammed landscapes. Dam removal provides a useful lens to consider the following: How do the historical and geographical contingencies of this region shape and alter conflicts over dam removal in specific ways? In instances where conflicts emerge, what do the conflicts reveal about the politics of ecological restoration in highly altered landscapes? We use a political ecology approach to reveal how complex cultural dynamics, competing interpretations of science and the environment, micropolitics, and the role of multiple actors generate and shape conflicts over dam removal. We show that the historical geography of New England influence conflicts over removal in important ways, particularly with regard to the roles of aesthetics and identity in landscapes that are characterized largely by consumptive as opposed to productive uses. Our findings also suggest that restoration in long-humanized landscapes will embroil new constellations of human and nonhuman actors, requiring attention to the political and cultural, as well as the ecological, dimensions of restoration. This paper contributes to research on the political and social dimensions of dam removal, as well as to research at the nexus of ecological restoration and environmental politics.
\end{abstract}

Key words: dam removal, river restoration, political ecology, environmental politics, weir removal

\section{Introduction}

In 2008, following an eight-year study by the United States Army Corps of Engineers (USACE), the Town of Greenfield, Massachusetts (MA) agreed to remove both the Wiley and Russell and Mill Street dams as part of a broader river restoration project on the Green River. After town officials determined that removing the Mill Street Dam would be too costly due to upstream infrastructure issues, the focus of the project shifted to the Wiley and Russell Dam. 
The dam, which the MA State Office of Dam Safety had previously labeled as "high hazard,"1 blocks passage for migratory fish such as American eel, blueback herring, sea lamprey, and Atlantic salmon. It is, according to nearly all independent estimates, an economic liability that no longer serves its original purpose of providing power to $19^{\text {th }}$ century industrial facilities. All told, 17 agencies and organizations, ranging from the National Ocean and Atmospheric Administration (NOAA) to Trout Unlimited, partnered in the proposed removal, spending $>\$ 500,000$ over five years. Yet, in August of 2014, after a campaign by community members concerned about the loss of the dam and the landscape that it created, which "have been an essential part of the ecosystem for 200 years,"2 the Mayor of Greenfield unilaterally decided to halt the removal.

Similar stories are emerging across New England. In Warren, Vermont (VT) local townsfolk are fighting to preserve the village's dilapidated crib dam (and surreptitiously repair it, if necessary) as a crucial element of the area's industrial heritage, while the VT Agency of Natural Resources (ANR), the dam's owner, has said that the structure is irredeemable and must go. In Durham, New Hampshire (NH), townspeople angrily protested in 2009 when state officials attempted to discuss removal of aging dams on the Oyster River (Figure 1). The proposal was subsequently dropped. In central Massachusetts, local residents galvanized a remarkably potent grassroots movement to protect a dam on the Swift River, with one man proclaiming that if "you kill the dam, you are killing a part of me" (Swift River Preservation Association, 2011). While many dam removals in New England have progressed with relatively little opposition, a significant number stall or fail completely, dividing communities (and even families), in the process. In contrast to the long-observed NIMBY ("not in my back yard") phenomenon (see van der Horst, 2007), "not out of my backyard" (NOOMBY) is rapidly becoming the informal rallying cry of the individuals and groups opposing dam removal in the region. ${ }^{3}$ The cases described above and others throughout New England raise intriguing questions about the political and social dimensions of efforts to restore, repair, or rehabilitate

\footnotetext{
${ }^{1}$ State agencies throughout New England define a dam's hazard according to the potential loss of human life and economic damages incurred should the dam fail ("high hazard"). In other words, the designation it is not a reflection of the dam's material condition.

${ }^{2} \mathrm{http}: / / \mathrm{www}$.industrialhistory.org/save-the-historic-wiley-and-russell-dam

${ }^{3}$ As van der Horst and others (e.g., Rootes, 2007; Michaud et al., 2008) rightly point out, NIMBYism as an explanation for individual and collective opposition to development projects or ecological interventions such as wind energy facilities is overly simplistic and must be invoked along side a greater sensitivity to proximity as a factor explaining opposition to a particular type of project.
} 
ecological systems in areas highly altered by human activities (Helford, 2000; Hobbs et al., 2011; Seastedt et al., 2008). Specifically, we ask: how do the historical and geographical contingencies of this region shape and alter conflicts over dam removal? In the instances where conflicts emerge in dam removal, what do those conflicts reveal about the politics of ecological restoration in highly altered landscapes? Accordingly, a goal of this paper is to investigate what the political ecology of dam removal in New England reveals about the changing nature of environmental conflicts and politics in what many have theorized as the Anthropocene epoch (Crutzen and Stoermer, 2000; Steffen et al., 2007; Castree, 2014; Ogden et al., 2013). Because environmental conflicts in the twenty-first century will increasingly center on intentional interventions to improve long-humanized landscapes according to specific (and often contested) ecological criteria, they will embroil new constellations of human and nonhuman actors, competing interpretations of nature, and complex cultural dynamics. An approach grounded in political ecology directs attention to the political and cultural dimensions of restoration, both of which could be more fully explored in the literature on ecological restoration.

Contested dam removals in New England are particularly interesting, since these conflicts are not primarily about access to and control over resources, which is often the case in other environmental conflicts across North America, where use of forests, restrictions on fishing, or access to land for grazing or mining are key issues (see Walker, 2003; Prudham, 2012). Rather, in this region conflicts over dam removal often involve a perceived loss of access to a cherished cultural and biophysical environment (the dammed landscape), as well as a sense among antiremoval voices that the dam removal process runs roughshod over community-based stewardship of "local" resources. The cases presented here contribute to a more robust understanding of environmental conflicts and environmental politics as played out in recent years in the US and further afield. Given recent calls to re-examine the epistemological and strategic foundations of US environmental politics (see Chaloupka, 2008; Buck, 2013) and, at a more global scale, to direct attention to multiple possible socioecological futures (see Braun, 2015; Mansfield et al., 2015), such an intervention seems timely. The paper proceeds with a discussion of a how a political-ecological approach facilitates a more critical examination of the political and social dimensions of ecological restoration by underscoring hitherto less visible aspects of the restoration literature. We also explicate our position on dam removal as a cogent example of a broad range of ecological interventions undertaken in the name of restoration. We then outline 
our methodological and epistemological framing, followed by a brief overview of the historical and current landscape of dams in New England. We follow with findings from our research, using key themes in political ecology to frame our analysis. We conclude with some thoughts on the implications of our findings for environmental politics and ecological interventions more generally.

\section{Figure 1: Halted and stalled dam removals}
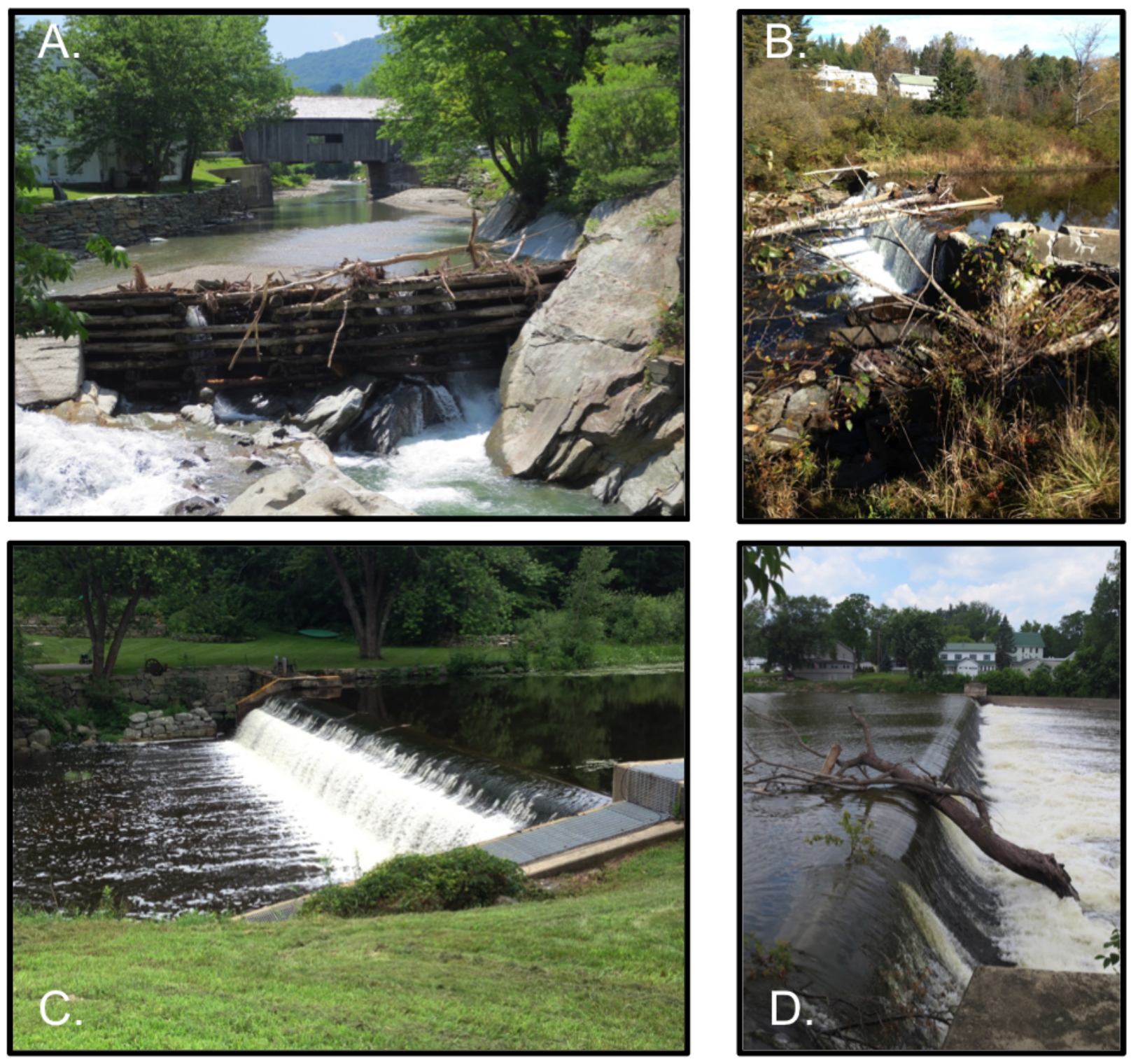
(A) Warren Dam
(B) East Burke Dam
(C) Mill Pond Dam (D) Swanton Dam 


\section{Interpreting conflicts over dam removal and restoration}

There are over 14,000 dams fragmenting the region's rivers (Magilligan et al., 2014), a wide majority constructed during the heyday of industrial water power in the $19^{\text {th }}$ and early $20^{\text {th }}$ centuries. For advocates, dam removal is often cast as the most important tool for restoring or rehabilitating degraded river systems in regions such as New England. This is perhaps best captured in the most commonly stated goal of river restoration advocates: "free-flowing rivers" (American Rivers, 2002, p. 1). Yet removal projects in New England have encountered a perhaps unexpected level of antagonism. Across New England, 127 dams have been removed as a result of intentional human action, ${ }^{4}$ and upwards of 50 more are either actively being removed or under consideration for removal. Although difficult to say with precision, a majority of these removal projects fomented some level of opposition from local stakeholders. Another 50 dams identified for potential removal by state agencies in New England have been stalled or delayed due to opposition on a variety of grounds. The number of contested removals is perhaps surprising given that the majority of the dams are relatively small, would be costly to repair, and rarely provide any direct economic benefits to local communities. Moreover, the environmental and safety benefits of removal are frequently significant. In other words, an outsider might not anticipate conflict, and dam removal would seem to be a logical and efficient use of time and resources to achieve both economic and ecological goals. Yet, the conflicts were surprising not only to us, as outsiders, but also to people who were involved much more directly in the dam removal process. We heard over and over again from dam removal advocates about how they were 'blind-sided' by the intensity of the opposition. Given these considerations, we perceive considerable conceptual value in examining the diverse and shifting ways that efforts to rehabilitate dammed rivers become politicized, while simultaneously emphasizing how intentional interventions into complex nature-society landscapes under the rubric of restoration are shaped by the material and cultural landscapes, historically contingent, of particular regions (Neumann, 2009).

\footnotetext{
${ }^{4}$ State agencies have identified several former dams as 'breached', implying they are only in part a barrier to river flows.
} 


\subsection{Politicizing restoration}

Scholarly and practical work on ecological restoration represents a broad range of natural and social scientific perspectives that coalesce around the normative goal of rehabilitating or repairing ecological systems perceived to be degraded or otherwise impaired by human activities. As a relatively young discipline and practice, ecological restoration is "experiencing growing pains", often in the form of critiques from scientists and practitioners, many of whom aim to improve outcomes and the likelihood of "success" of specific restoration initiatives (Suding, 2011, p. 466). Because restoration focuses on "reestablishing an ecologically healthy relationship between nature and culture" (Wisenant, 2011, p. 207), it also invites critical inquiry about the relationship of humans to the natural world. Geographers and scholars in related fields have begun to raise these questions in a variety of institutional and ecological contexts. This is demonstrated in several cases: wetlands and stream restoration initiated under the rubric of mitigation banking (Robertson, 2000, 2006; Lave, 2008, 2012a, 2012b, 2014); habitat restoration for iconic endangered species (Gross, 2008); restoration in the face of widespread invasive species in Australia (Trigger et al., 2008); forest restoration efforts in the Midwestern United States (Law and McSweeney, 2013); clashes over cultural and ecological values in Everglades restoration (Zweig and Kitchens, 2010); initiatives to "rewild" select European landscapes (Lorimer and Driessen, 2014); contrasting visions of science in restoration projects at arboreta in the Midwest (Weng, 2015); cultural concerns about restoration projects in the Lower Colorado River and basin (Varady et al., 2001); and calls for greater attention to the complex political and institutional context of restoration projects around the world (Baker et al., 2014)

For dam removal in New England, the politicization of restoration is deeply intertwined with history, as interpretations of past landscapes have become focal points of conflict. While restoration ecology has moved away from explicitly seeking to return an ecosystem to its "historical trajectory" (Society for Ecological Restoration, 2004; see also Wohl et al., 2015) or to recapture the "myth of a lost paradise" (Dufour and Piegay, 2009), historical thinking still plays a critical role in contestations over restoring rivers in highly altered ecosystems. This reflects the lack of consensus within the restoration community, among both scientists and advocates alike, regarding the precise biophysical endpoints of their efforts. As Jørgensen (2014, p. 1) reminds us, scientists may "agree that they are trying to re-instate something, they just do not agree what that 
something should be."

Our research thus adds to a growing literature focused on river and stream restoration that encourages a rethinking of the cultural and political-economic processes that are often farremoved from restoration advocates' ecological goals, but nevertheless drive restoration activities (Thompson, 2013; Lave, 2012a; Eden et al., 2000; Tadaki et al., 2014). This research includes consideration of human benefits in setting river restoration goals in Western Europe (Dufour and Piegay, 2009); varying perceptions of river restoration success in Germany (Jahnig, et al., 2011); the role of science and value-based inputs in the restoration of a river in British Columbia (Failing et al., 2012); the role of indigenous communities and traditional knowledge in river restoration and management (Salmond et al., 2014); environmental framings in river restoration (Emery et al., 2013); the nature-culture interface in river restoration projects (Eden et al., 2000; Eden and Tunstall, 2006); and questions about the "naturalness" of a revitalized urban river in Seoul, South Korea that is completely reliant on infrastructural innovations for its ecological and aesthetic functions (Busquets, 2011; Reed, 2011). Our research on dam removal builds on this work, raising questions about how we might imagine possible "socioecolgocial futures" of river ecosystems through restoration processes (Holifield and Schuelke, 2015, p. 297) and about how politics and values become intertwined in such interventions (Tadaki and Sinner, 2014). This is valuable because most research on the social and political aspects of dam removal as river restoration has tended to be narrow in scope, to assume a managerial attitude focused on facilitating removals, or has remained under-theorized (see Johnson and Graber, 2002; Gosnell and Kelly, 2010; Jorgenson and Renofalt, 2012). A political ecology framework helps better conceptualize the practices of ecological restoration by emphasizing how processes of environmental knowledge production both shape and are shaped by the political and cultural dynamics of specific locales. ${ }^{5}$ Research on river and stream restoration in general (and dam removal in particular) would also benefit from deeper engagement with the ways in which seemingly straightforward restoration initiatives can become enmeshed in social and political conflicts, or indeed how purportedly scientifically designed restoration approaches are always

\footnotetext{
5 Rikoon's (2006) work on contestations over the removal of non-native "wild" horses in the Ozarks region of central Missouri is an example of research that takes a similar approach. Although not central to her analysis, Ogden's (2008) exploration of the ecosystem as applied to the history of Florida's Everglades restoration programs is also theoretically relevant to the arguments we make here.
} 
already expressions of social power (see Eden and Tunstall, 2006). ${ }^{6}$

The messy connections between politics and scientific knowledge are underscored in debates among physical scientists regarding the value of different approaches and techniques in river restoration, as evidenced by the 'Rosgen wars' (see Lave, 2008, 2012b, 2014), which refer to disputes about the classification approach to channel design (Small and Doyle, 2012). ${ }^{7}$ The political-economic stakes are high: at present within the United States, river restoration is a \$1 billion a year industry (Bernhardt et al., 2005) ranging in techniques from bank stabilization, channel reconfiguration, floodplain reconnection, fish passage, in-stream habitat improvement, to dam removal/retro-fitting. While researchers and practitioners might disagree on methodologies and particular aspects of channel design and other physical interventions, river restoration overall remains characterized by engineering and technological approaches, with interventions generally executed at the reach scale, which means they are spatially restricted and carefully controlled. Dam removal is somewhat different in this regard. While supported by considerable scientific expertise, there is much less scientific certainty regarding the magnitude and spatial extent of the restoration response than in other river restoration projects. Every dam removal is a singular experiment, guided by certain expectations based on river science and boundary conditions, but also characterized by uncertainty (Grant and Lewis, 2015). This uncertainty is further compounded by a lack of pre- and post-restoration monitoring efforts (Downs and Kondolf, 2002; Palmer et al., 2005; Bernhardt et al., 2005), and, more importantly by a lack of well articulated project motivations or goals (Bernhardt et al., 2005; Bernhardt et al., 2007). ${ }^{8}$ These broad approaches, including dam removal, defy a unifying underlying scientific method or a single metric of success, leading some restoration scientists to appeal for better science to evaluate the effectiveness of restoration efforts altogether (Palmer and Bernhardt, 2006).

\footnotetext{
${ }^{6}$ Research on divergent environmental framings in a river restoration conflict in northern England represents an important contribution in this regard (Emery et al., 2013). In a different vein, recent work in Australia has fruitfully explored how communities' sense of history and belonging directed at specific landscapes can profoundly influence state-initiated river rehabilitation programs (Spink et al., 2010).

${ }^{7}$ While prominent in much of the United States, the debates over Rosgen's stream classification methods and its "recipe book" for stream restoration, as well as stream mitigation banking, expertly delineated by Lave (2012b), are largely inconsequential in New England.

${ }^{8}$ Bernhardt et al. (2005) reported that less than $20 \%$ of the $\sim 3700$ projects in their database had any listed goals whatsoever, or at best, these restoration projects merely stated "to restore ecosystems", and that less than $10 \%$ of the projects were not designed to disseminate monitoring results or even, at a minimum, to evaluate the overall consequences of implemented restoration efforts.
} 


\subsection{Dam removal as restoration}

While restoration ecology has emerged as an important site of scientific knowledge production (both in the biophysical and social sciences), dam removal in New England is frequently characterized via different discourses by proponents and opponents alike. For removal advocates in state agencies and environmental organizations, while certainly able to employ the rhetoric of stream restoration for their colleagues and environmentally-minded audiences, appeals for removal are more often than not made on the grounds of dam safety (the structure is "falling apart") and economics (repairing dams is "too costly"), particularly when communicating with local residents at public forums. Conversely, the community residents seeking to preserve a particular dam actively contest the notion of ecological restoration, arguing instead that dam removals are quintessentially about cultural and ecological disruption of cherished and historically significant landscapes.

However, understanding dam removal as restoration does provide an important if somewhat conflicted lens through which to evaluate and frame the micro- and regional politics of river restoration, and hopefully contributes to the vibrant debates now emerging around ecological restoration. Seeing dam removal as a component of ecological restoration is especially crucial in a region like New England, where the pervasive legacy of industrialization remains especially manifest; where local, reach-scale restoration efforts (e.g. "natural channel design") rarely occur; where neoliberal privatization efforts, such as mitigation banking (Robertson, 2006; Lave et al., 2010) are scant; and where dam removal is often perceived by local NGOs as the best tool in the restoration toolkit to achieve watershed-scale restoration (Magilligan et al., in review). As noted previously, dam removal diverges from other forms of river restoration practically

(how it is achieved) and scientifically (what it hopes to achieve), and it generates significantly different forms of conflict, ultimately providing new insights into the enactment and rhetoric of environmental conflict. Conflicts over dam removal more often than not orbit around value conflicts or other more fundamentally binarized ideological differences: i.e., either the dam remains or gets removed. Other restoration efforts (e.g., natural channel design, bank stabilization, green-spacing river corridors) generate more of what political scientist Bill Lord calls interest conflicts (Lord, 1979), where multiple options exist in its implementation and 
where stakeholders lobby for or against the particularities of what is being proposed, what they hope to achieve, and the scientific merits substantiating a particular approach. This often occurs in a top-down institutional setting where the conflicts are not necessarily about whether the restoration effort should be done, but whether it meets the necessities of regulatory demands such as satisfying EPA requirements (Rhoads et al., 1999) or other components of the Clean Water Act (Tadaki and Sinner, 2014). In these latter cases, participatory politics, environmental governance, and constitutive knowledge production frame the contours of river restoration, but the argument rarely contests the potential teleological aspirations or outcomes of river restoration. In other words, most conflicts embedded in the river restoration discourse are more about the means, not the ends, while for dam removal, the conflicts are situated less in how it is to be done but more if it should be done at all.

Despite these observations, there are important overlapping dimensions between dam removal and broader river restoration approaches, especially regarding real or imagined asymmetric power relationships, contested scientific knowledge and expertise, fragmented institutional settings, historical claims to nature, scalar politics, and contested visions over what the restored landscape should resemble (Rhoads et al., 1999; Urban, 2005; Robertson, 2006; Tadaki and Sinner, 2014; Holifield and Schuelke, 2015; Wohl et al., 2015). These dimensions are aptly demonstrated in the cases of conflict over dam removals in New England

\subsection{Conceptual and methodological approach}

In an effort to embed conflicts over dam removal firmly within the historical and geographical circumstances of a territorial configuration, our research builds on appeals to take regions - in all their constructedness and complexity - more seriously in political ecological research (Walker, 2003; Pincetl et al., 2011). In this light, it is crucial not to overly generalize the human-environment relations occurring within specific regions, but instead to recognize that there are shared and historically specific processes "wherein the reproduction and transformation of society is inseparable from the transformation of nature within prevailing relations of power" (Neumann, 2009, p. 374). Working in a similar vein and under the broad rubric of first world political ecology, scholars have in the past decade shed light on instances of environmental conflict throughout the US, particularly since McCarthy's $(2001,2002)$ seminal work on the 
Wise Use movement in the western US. ${ }^{9}$ Throughout his work, McCarthy argues that the broad themes of political ecology could contribute to understanding environmental relations and conflicts in the industrialized world. There is now a wide range of research drawing on political ecological concepts in the United States, ranging from studies of coastal development in North Carolina (Campbell and Meletis, 2011), local knowledge and fisheries in Alaska (Holen, 2004), environmental knowledge in Yellowstone National Park (Robbins, 2006), the 'ex-urban' Sierra (Walker and Fortmann, 2003), the peculiarly American obsession with suburban lawnscapes (Robbins and Sharp, 2003; Robbins, 2007), and the role of smallholders in facilitating reforestation in southern Ohio (Law and McSweeney, 2013).

To interpret our findings and inform our analysis, we draw on key concepts associated with a political ecology approach — many of them exemplified in the work above - that intersect with the themes that emerged from research participants' experiences with removal. First, we look to research on the intermingled roles of history and identity in fomenting landscape politics, particularly in landscapes of consumption (Walker and Fortmann, 2003; Robbins, 2007). ${ }^{10}$ This theme draws attention to how dams relate to "regional identity, history, and personal experience", often becoming "core symbols of communities", which are defended through the use of "personalized and detailed rhetoric" and therefore reflect identities that are "deeply entwined with the landscape" (Rikoon, 2006, p. 200, 207). ${ }^{11}$ Second, we foreground discussions regarding the role of environmental knowledge in framing and fuelling ecological conflicts (see Forsyth, 2003). This involves "rethinking environmental 'knowledge"” (Robbins, 2006, p. 190) and recognizing competing interpretations of natural processes, whereby "knowledge is not something an individual has 'more' or 'less' of, but rather reflects the specific forms of practice undertaken in daily life; thick in some areas, thin in others, knowledge is embedded in daily political and environmental activity" (Ibid., p. 191). We then delve into how our two central themes - historically tinged landscape identities and divergent environmental knowledges — fuel

\footnotetext{
${ }^{9}$ We recognize the deeply problematic character of the "third" and "first" designations, but reproduce them here as a means of engaging with the cogent arguments within political ecology over the past several years regarding the need to move beyond geographically rigid categorizations of phenomena.

${ }^{10}$ Landscapes of consumption can be understood in contrast to landscapes of production, which are ones that provide material benefits and tangible resources such as grazing concessions, agricultural lands, and forests.

Landscapes of consumption often refer to areas that have scenic or rural qualities, and which are attractive to tourists or residents for reasons related to aesthetics or notions of a "rural idyll" (Abrams and Gosnell, 2012; Walker and Fortmann, 2003).

${ }^{11}$ Rikoon's (2006) research is on wild horses, but the themes are very relevant to our research.
} 
dynamic micropolitics of ecological restoration and dam removal in New England. An explicit emphasis on micro-politics (or the rather unwieldy "micropolitical ecology") of ecological conflicts shifts attention to "local particularities and the importance of interactions among individuals in influencing environmental outcomes" (Horowitz, 2008, p. 260), and seeks to explain the "resolute defense of the local" (McCarthy, 2002, p. 1283) that characterize many of these conflicts. ${ }^{12}$

Our analysis draws on a selection of stalled or failed dams removals, which reflect a range of institutional contexts (i.e., the blend of local, state, and national jurisdictions guiding the removal process) and varying levels of conflict over the removal process (e.g., organized versus unorganized opposition to removal). We chose cases that were representative of the issues that we saw in our wider sample of contested removals. We use semi-structured interviews to query the key actors to determine the economic, political and cultural factors driving conflict in each case. Semi-structured interviews are powerful methods for obtaining information about social conflicts because they can fill in gaps in knowledge arising from more quantitative data, provide insight into the often complex motivations driving conflict, and accommodate a diversity of perspectives (Dunn, 2000). Information provided through the interview process is supplemented with accounts of dam removal conflicts and processes contained in newspapers and other media, transcripts of local and state hearings, and other textual sources. Our research team (two social scientists and a fluvial geomorphologist) also observed public meetings and information sessions to ascertain the themes of concern evident among the different stakeholders. Both interviews and observation enable identification of "the complex of narratives and ideologies" that sustain certain ideas regarding both the dammed and the undammed landscape (see Duncan and Duncan, 2004, p. 38) as professed by proponents and opponents. Once collected, we searched through informants' responses with an eye to the most prominent discourses surrounding resistance to removal, as well as participants' description of their motivations for resisting removal initiatives. While we focus here on the perspective of removal opponents, we understand their perspectives against the views and experiences of removal advocates in a wide range of government agencies and non-governmental organizations active in dam removal projects throughout New England.

\footnotetext{
12 The call for greater attention to micropolitics within political ecology and the study of nature-society relations is hardly novel, as evidenced by Neumann's (1992) early argument that the field would be better positioned to understand environmental conflicts by directing attention to politics occurring informally and at smaller spatial scales.
} 


\section{New England's dammed landscapes}

As a set of landscapes, New England is partly defined as a region by the wide-ranging transformation of its landscapes via damming of its river systems - primarily to provide power for industrial purposes (see Hunter, 1979)_over the past two centuries. New England has the highest density of dams (small-, medium-, and large-scale) relative to other regions of the US. ${ }^{13}$ More than 14,000 dams fragment the region's watersheds, and it is difficult to overstate the profound biophysical alterations brought about by dams built in New England over the $19^{\text {th }}$ and $20^{\text {th }}$ centuries. Both the individual and cumulative ecological impacts of New England dams are significant (Saunders, 2006; Hall et al., 2011; Opperman, 2011). Some environmental impacts are "immediate and obvious", such as the obstruction of pathways for migratory fish or the trapping of sediment behind reservoirs and the inundation of habitats (Nilsson and Berggren, 2000, p. 784). Other impacts, such as those associated with altered geomorphic and hydrologic processes, may be more gradual or harder to discern immediately (Curtis et al., 2010). In New England, dams were the primary cause of the decline of river fisheries. In the early $1800 \mathrm{~s}$, alewives, American shad, and salmon were still abundant in the region's river. By 1900, most of these species were commercially extinct. Even though there were other pressures on fisheries, the "decisive element of destruction in all the major watersheds of New England was the construction of dams across rivers of any considerable flow to provide power for the region's development industrial economy" (Vickers, 2004, 686). ${ }^{14}$ As these structures' original functions — water power for machinery and later hydroelectricity production — were made irrelevant due to broader political economic changes in the later $20^{\text {th }}$ century, their value as elements of local systems of capitalist production, and their value to local communities as such, waned as well. While the industries are gone and the landscapes are no longer productive, the dams linger and the barriers to fish passage remain.

\footnotetext{
${ }^{13}$ The number of dams varies by state, with New Hampshire having the most (5076) and Rhode Island the least (668). Connecticut has 3624 dams, New Hampshire has 5076, Massachusetts has 3002, Vermont has 1027, and Maine has 760 dams (Magilligan et al. 2014).

${ }^{14}$ Contrary to common sense assumptions about overwhelmingly favorable attitudes towards dam construction in the United States during the $19^{\text {th }}$ and most of the 20 the century, many of New England's water power dams were hotly contested, primarily by communities concerned over the loss of farming areas (due to floods) and access to important fisheries. Many of the affected residents of the upper Merrimack watershed, for example, fought these battles through the court system (Steinberg, 1991; Hunter, 1979).
} 
Indeed, only a small percentage serving their original purpose, which was often to power mills beginning in the 1800s (Hunter, 1979; Steinberg, 1991). For example, of the 3,000 dams in Massachusetts, only about 10 percent provide energy, flood control, or drinking water (American Rivers, 2013). Moreover, many of the dams peppered throughout the region as part of formerly productive landscapes are ageing and subject to costly repairs, which owners are unwilling to fund. This dilemma is well illustrated by the town-owned Mill Pond Dam on the Oyster River in Durham, NH, which has been issued two letters of deficiency by the state. The dam was built in the $18^{\text {th }}$ century to harness waterpower for mills, but has not served that purpose since 1913. Rather, it functions as a "scenic icon" with "historic, recreational and social value that is hard to put a dollar value to" (Sanborn, 2009). Local officials estimate that it would cost as much as \$1.7 million to repair. ${ }^{15}$ The prolonged process in Durham points to another way that the politics of restoration and dam removal play out in this region. Local bodies in New England (e.g., selectboards, town councils, historic commissions) have a comparatively large amount of decision-making power to influence policies that affect local infrastructure in ways that may not be possible in other regions of the country (Ryan, 2006). Dam removal typically involves a lengthy period of public discussion with the opportunity for multiple actors (e.g., local residents, local and extra-local government officials, representatives of environmental organizations) to frame and express their positions surrounding dam removal. Furthermore, in the face of apathy about removal or repair from a majority of community members, relatively small groups of antiremoval advocates can exert inordinate influence over town-level decision making processes through careful arguments - whether founded on biophysical knowledge or not-regarding the potential of removal to irrevocably alter the "character" of a landscape in an undesirable way.

It is within this context - a region where landscapes have been radically altered for productive purposes that for the most part no longer remain relevant - that dam removal has accelerated. The number of removals varies by state, with Massachusetts having removed 31 dams and Rhode Island only four. Environmental organizations and environment-oriented state agencies in New England have generally taken the lead in these cases, seeing dam removal as part of a broader strategy to restore coastal ecosystems and migratory fish species along the Atlantic coast (American Rivers, 2010; NOAA, 2012). However, there is little to suggest that the

\footnotetext{
${ }^{15}$ Interview, New Hampshire Department of Environmental Services, January 19, 2009
} 
removals executed so far have done much to reestablish the region's historic fish migrations. The pattern of removal thus far reflects not a top-down, coordinated strategy to protect diadramous fish, but reveals a regional landscape of "strategic opportunism."16 Importantly, although not necessarily achieving stated regional goals, removal has had enormous ecological benefits, opening up over 3700 kilometers of free-flowing river and improving habitat for resident aquatic species (Magilligan et al., 2014). Given these impacts, it is worth considering in much finer detail the rationales behind opposition to dam removal, and how dam removals in New England might suggest a new way of interpreting environmental conflicts.

\section{Contesting dam removal: History, knowledge, and micropolitics}

The human and nonhuman factors that influence the trajectory of a dam's removal or its preservation are multiple and interrelated. These factors include, for example, the dam's age, its hazard/liability status, its proximity to residents' homes and travel habits, the number and tenacity of pro-removal advocates, perceptions of what counts as scientific knowledge, the involvement of local, state, and Federal management agencies, and many more. For the purposes of this paper, we focus on those features that begin to explain why several removal projects in New England have been contested by people living within or near the dammed landscape, or who express a type of connection to that landscape. In this instance, dams have become crucial parts of individuals' and communities' perceptible realms (Gobster et al., 2007), where aesthetics, sense of place, and environmental knowledge come together to influence perceptions of and attachment to landscapes. When these landscapes are threatened with what is perceived as radical change, residents often react with anger, distress, and, most importantly for our work, concrete social actions to defend the place under duress (Devine-Wright, 2013, pp. 62-63). ${ }^{17}$ Focusing on these contestations of landscapes' materiality and meaning reveals the often hidden, quotidian political ecologies at work in specific locales that we argue are important elements of contemporary environmental conflicts.

\footnotetext{
${ }^{16}$ Throughout our interviews, this phrase was repeatedly invoked by representatives of state and Federal agencies, as well as environment organizations, working in New England as the most apt description of their organizing approach to advocating dam removal.

${ }^{17}$ In this article, we have opted to focus on the political activities through which people's attachment to familiar landscapes is channeled; accordingly, a fuller account of place attachment is beyond the scope of this work. For excellent overviews of place attachment at individual and community levels, see Vorkinn and Riese (2001) and Antonsich (2010). There is now a rich and evolving dialogue between geography and environmental psychology concerning how place attachment might manifest at several spatial scales (Devine-Wright, 2013).
} 


\section{1 "If the dam is on the town seal:" History and identity}

The intertwined roles of history, identity, and aesthetics - and how they coalesce to create attachment to place and inspire the defense of a dammed landscape - are critically important to understanding anti-removal sentiments in New England. Powerful attachments to landscapes emerge as a result of "experiential events and specific encounters", whereby local identities become "deeply entwined in constructions of the landscape" (Rikoon, 2006, p. 207). As discussed earlier, in many New England towns, "dams are a central part of the community ... they are a visual cue to the past". ${ }^{18}$ The community becomes accustomed to the altered landscape, and "they can't envision that it would be beautiful without the dam". ${ }^{19}$ One resident of Warren, VT compared the local dam to a "monument" that signified an important moment in history (Figure 1). He noted: "Warren was the industrial part of the valley. Houses came as a result of the crib dam". ${ }^{20}$ The landscape created by the 200 -year old crib dam, waterfall, pond and bridge is, according to local residents "one of the most photographed sites in Vermont and, it could be argued, is an essential part of the single most important resource in the town - its beauty" ${ }^{21}$ As a staff member from the Vermont Council of Natural Resources (in general a removal advocate), observes about the Warren Dam:

[It] is the poster child for dams that, even though it should come out, it's a dam you don't want to take out because it's on the town seal. Rule 101 of dam removal is don't go after the dams that are on the town seal... They want to keep it as part of their culture and history. ${ }^{22}$

Similarly, the Swanton Dam on the Missisquoi River in Vermont, in the words of the town administrator, becomes "part of our history, part of our culture ... it's been there for years" (quoted in Thompson, 2008)(Figure 1). In fact, while there has been a dam on the Missisquoi since 1790, the current dam, and focal point of conflict, has only been there since 1960.

Importantly, the attachment that people feel is not only to the dam facing elimination. Rather, the attachment is to a more broadly defined historical landscape, whereby "It's not just the dam, but what happens to the resources around it...We look at a resource holistically. The

\footnotetext{
${ }^{18}$ Interview, New Hampshire State Historic Preservation Office, August 7, 2014

${ }^{19}$ Interview, Vermont Agency of Natural Resources, July 17, 2013

${ }^{20}$ Warren Dam Preservation Society meeting, Warren, Vt., February 4, 2014

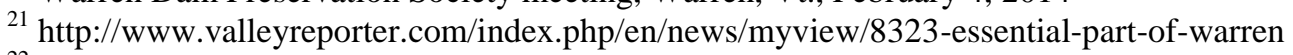

${ }^{22}$ Interview, Vermont Natural Resources Council, July 17, 2013
} 
mill, the dam, the impoundment...The dam might not be historical itself, but it might be part of an historical element". ${ }^{23}$ This expansive definition of the historical landscape is indicative of the multiple interpretations assigned to consumptive landscapes, which further complicates the environmental conflict that results. Referring to the Swanton Dam, the town select board chair noted: "A $\$ 2.8$ million dollar bridge that has a scenic and beautiful view, if you take out the water underneath it, it just doesn't make sense to have that beautiful bridge with no water underneath it. And that's the town's position". ${ }^{24}$ In the case of the Warren Dam on Vermont's Mad River, the attachment is not only to the dam but also to the "resulting waterfall and mill pond with its covered bridge ... [the dam] represents a key anchor element of the historic fabric in a well-known National Historic Register District". ${ }^{25}$ For the Mill Pond Dam in Durham, NH, it is the "mill and the dam together [that] should've been saved for history ... Once history is gone it's gone forever" (quoted in Sanborn, 2009). Similarly, the Faulkner and Colony Dam on the Ashuelot River in NH is valued as evidence of the area's industrial history, a "rare and integral element of what made Keene today" (cited in Spegman, 2012). As the above examples clarify, support of maintaining dams for their historical value is often linked to the broader landscape. These different elements constitute an historical package that is deeply meaningful to many local residents who express grave concern about its potential loss.

This is clearly seen in cases where a historical sensibility fuels current conflicts and reflects community identities. Dams such as the Wiley and Russell on the Green River are seen as "key to the region's history ... because water power is such a component to the history. It all literally starts here . . . Late 1600s there was a mill here". ${ }^{26}$ The dam and old mill become central to the neighborhood identity, as two community members reflect when discussing the proposed removal:

And that neighborhood, this whole neighborhood, has an historical cohesiveness to it, because it was a factory village, you know, the historical commission has it designated that way. So when the neighbors down here, a lot of them didn't know this was going to happen, and once they found out, they saw it as their neighborhood being destructed, more than on just like a scenic level. ${ }^{27}$

\footnotetext{
${ }^{23}$ Interview, New Hampshire State Historic Preservation Office, August 7, 2013

${ }^{24}$ Cited in http://www.wcax.com/story/10833762/should-swanton-dam-be-removed

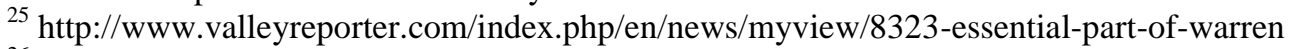

${ }^{26}$ Interview, Museum of Our Industrial Heritage, Greenfield, Mass. September 23, 2014

${ }^{27}$ Ibid.
} 
When a dam such as the Wiley and Russell is targeted for removal, the structure can become the focus of the "performance of place," as locals seek to raise awareness about the historic and aesthetic values associated with these structures (see Buizer and Turnhout, 2011). The failed effort to remove the Upper Bondsville Dam on the Swift River near Belchertown, MA speaks to how community members performed place in response to powerful attachments to dam-created landscapes, in ways that go beyond mere connection to regional and local histories. After abandonment by its former owner, the Belchertown Land Trust, Inc. (BLT) purchased the land enclosing the dam site in 2005. When state officials found the dam to be structurally unsound, the BLT indicated that it had neither interest in nor funds for restoring the dam. Subsequently, state officials and environmental groups offered to proceed with the dam removal process, and expressed a high likelihood that funds for removal could be secured through Federal agencies and national environmental groups. In response, local residents formed the Swift River Preservation Association (SRPA) to defend the dam and its 25-hectare reservoir in the name of "preserving" the Swift River and began educating the public with a website about how removal will "drain the Swift River" and otherwise damage an "integral part of the community" (SRPA, 2012). As the name of the organization suggests, members equated preservation of the dam with preservation of the river and associated landscape. This attachment to the landscape is not just about aesthetics, but also about personal experience of the place. A local kayaker on the Swift River reservoir noted, "I found a new wonderland in my backyard. To have it erased from earth would be a sin" (Ibid.). Another community member described how the site was a link between generations, and that "My parents enjoyed it. I enjoy it. My children enjoy it, and hopefully one day my grandchildren can enjoy it" (Ibid).

As these examples make clear, there is often a "memory factor" that drives resistance to a dam's elimination; people simply do not want to lose what is perceived by many as a focal point of the landscape and community. ${ }^{28}$ While on occasion a dam's historical importance is overstated in order to test out different political strategies, conflicts around the removal of New England's dams are deeply informed by communities' historically-inflected identification with the dammed landscape. Oftentimes these connections are also pegged to very specific kinds of environmental knowledge, which in turn informs what counts as "nature".

\footnotetext{
${ }^{28}$ Interview, N.H. Department of Environmental Services, Jan. 19, 2009
} 


\section{2 "Nature worth preserving": Environmental knowledges}

Our findings also highlight the central role of environmental knowledge and perceptions of nature in framing and fuelling ecological conflicts over dam removals. There is nothing novel about observances of how nature is socially constructed through scientific, cultural, and political mindsets and institutions (see Demeritt, 2002), but we argue it is critically important to tease out precisely how constructions of "the natural" matter in the context of environmental politics and ecological conflicts. Very often the novel ecosystem created by a dam inspires defense because it is perceived by nearby residents and other landscape users as a version of nature worth preserving in its own right. For example, the Friends of the Upper Roberts Meadow Reservoir and Upper Roberts Meadow dam on the Mill River in Northampton, MA have launched a grassroots effort to preserve the structure in order to "protect an important wildlife habitat and protect a rare water vista at this site", which they understand as "a beautiful spot where even the casual passerby might glimpse a river otter or blue heron, Merganser ducks, beaver, or even a kingfisher. The wildlife living here depend upon this established habitat". ${ }^{29}$ Similarly, the SRPA envisions itself as a defender of nature, and they are working to "leave the Swift River as it is ... [to] preserve nature", because "draining the resource would not only affect the community but would have drastic effects on the flora and fauna of the area." Community members come to understand the reservoir as a "beautiful ecosystem" and exhort those interested in dam removal to "stop messing with what is left of our wildlife." One defender of the ecosystem signed a petition (see Table 1) to save the dam "on behalf of the creatures who live in the wetlands" (SRPA, 2011). ${ }^{30}$ As a community member noted of the pond behind the Wiley and Russell Dam, "the wildlife is amazing down here. It's just that nobody ever gets the chance to see it ... [there are] egrets, beaver, merganser ducks, mink, a ton of mink ... I've seen [them] pulling two pound trout out of the river". ${ }^{31}$ Often the ecosystems that people become attached could be described as "artificial ecosystems" and include non-native species such as sunfish, bass, mute swans, and phragmites. ${ }^{32}$

\footnotetext{
${ }^{29} \mathrm{https}: / /$ sites.google.com/site/savethechesterfieldroaddam/home

${ }^{30}$ The great irony of appeals to the Swift River's "natural" condition is that the Swift in this region is bookended by the downstream Upper Bondsville Dam and upstream by one of the dams that formed the massive Quabbin Resrvoir in central Massachusetts, built in the 1930s to supply the city of Boston, MA with a sustainable water source.

${ }^{31}$ Interview, Museum of our Industrial Heritage, Greenfield, Mass., Sept. 23, 2014

${ }^{32}$ Inter Connecticut- DEEP/Inland Fisheries Division, Feb. 13, 2015
} 
In all of these cases, who gets to interpret what is a "better" environment is an open question with potentially high socioecological stakes and which reinforces the divergence of views on nature in the early $21^{\text {st }}$ century. The uncertainty associated with dam removal creates opportunities for people to contest "scientific" predictions about how a river will respond to removal. On occasion people make assumptions about ecological outcomes that have no basis in biophysical understandings of river systems, but can still delay a dam's removal. Concern over the recovery of lampreys in New England rivers is a good example of this. In the case of the Amethyst Brook Dam removal in Massachusetts, late in the project someone:

raised concerns about reintroducing sea lamprey into the system and . . . actually went around and had, I want to say, forty or fifty neighbors sign a petition to not do it because of concerns about ruining the local trout population. And we ended up having a seventh or eighth public hearing that was well attended by probably forty people. And we just made a presentation on sea lamprey, you know, and after a couple of hours those concerns evaporated because there's no risk whatsoever because sea lamprey, when they come into the fresh water, they're blind and have no teeth. So there's no feeding and there's no risk to you or the fish, because they just come up to die and spawn. ${ }^{33}$

While it is certainly accurate that sea lampreys are invasive in the Great Lakes region and have done a great deal of harm to certain native species, they are indigenous to New England's waterways and do not pose a threat to other fish. In the case of the failed Wiley and Russell Dam removal, community members expressed concerns about lamprey bothering swimmers once the dam was removed, but there is no evidence of this ever occurring. ${ }^{34}$

Other times, there is very little confidence in expert knowledge. People are worried that the river "is just going to dry up" "35, or that it will be become a "stinky mud flat"36 once the reservoir is drained. This is a powerful image that can be very worrisome for people who live near the dam or recreate on the reservoir. In discussions about the Wiley and Russell Dam, community members were not convinced by the scientific and engineering studies that stressed the benefits of restoring the Green River to a more natural, pre-dammed state. As one removal opponent noted with regard to the stability of the area around the dam, there had been "major landslides" on the "whole plateau going west that's just sand and gravel," which for this person

\footnotetext{
${ }^{33}$ Interview, Massachusetts Riverways, July 24, 2013

${ }^{34}$ Interview, Connecticut River Watershed Council, Sept. 23, 2014

${ }^{35}$ Interview, American Rivers, Nov. 17, 2011

${ }^{36}$ Interview, Connecticut DEEP - Inland Fisheries Division, Feb. 13, 2015
} 
raised the question of "what is really going to happen" once the dam is taken out. ${ }^{37}$ With regard to this case, a staff member who was working with the Connecticut River Watershed Council to facilitate dam removal noted that anti-removal advocates simply "did not trust anything that our consultants would have said" about what an undammed river might have looked like. ${ }^{38}$

\section{Table 1: Citizen/stakeholder responses to the "Save the Bondsville Dam and Swift River" Facebook petition}

- Leave the Swift River as it us. Preserve nature!

- Save the Dam. Save nature. Save fun.

- Stop messing with what is left of our wild life.

- This is a great recreational area as well as an established ecosystem. Draining the resource would not only affect the community but would have drastic effects on the flora and fauna of the area.

- Why devastate a pristine natural area.

- It would be a shame to lose this beautiful natural resource.

- The swift river has been part of me since I was a little kid. You kill the dam, you are killing part of me.

- Saving wildlife and wetlands for the future is an important part of our lives and the lives of our children etc.

- Save the dam and the unique ecosystem for future generations to appreciate. (SRPA, 2011)

These instances highlight the diverse types of environmental knowledge brought to bear on how "nature" is defined, and underscores how different constructions of nature precipitate conflicts over dam removals and river restoration programs. But more than this, they emphasize a politics of the environment - its material characteristics and its identity as a cultural landscape - as a far more open question. It is not novel to argue that "nature is in the eye of the beholder;" it may be novel, however, to see invocations of anthropogenic landscapes mobilized within environmental politics as paragons of "pristine" nature (Table 1).

\section{3 'David versus Goliath': The micropolitics of dam removal}

According to the Director of River Restoration at American Rivers, the "most basic challenge" for proponents of dam removal is "that people don't like change" (quoted in Walton, 2015). This was a refrain we encountered numerous times in our conversations with removal

\footnotetext{
${ }^{37}$ Interview, Connecticut River Watershed Council, Sept. 23, 2014

38 Ibid.
} 
advocates, whether voiced by representatives of Federal and state resource management agencies or environmental NGOs. At one level, such a response is understandable. However, our inkling is that there are socio-natural forces at work other than mere resistance to change of nearly any kind. This section seeks to make these forces more visible by examining in more detail the micropolitics of dam removal. For our purposes, this can be defined as a kind of quotidian environmental politics that plays out in multiple locales across the planet as individuals and collectives struggle over and with the uses and meanings of specific landscapes. Exemplary cases can be found in southern Africa (Moore, 1998), the western United States (Walker and Fortmann, 2003), in South Carolina (Hurley and Halfacre, 2011), and southwestern Niger (Batterbury, 2001). A focus on micropolitics brings us into the world of "human dispositions, moods, and cultural ensembles" without which broader goals of greening political-economic relations at transnational and domestic scales are hardly imaginable (Bennett, 2010, p. xii).

Opponents of state-initiated and sponsored programs of ecological restoration often perceive the defense of altered landscapes in terms of overcoming longstanding and structural inequities that manifest through government and environmentalist circuits or even through regional biases (see Law and McSweeney, 2013). This is frequently framed as an insider versus outsider narrative. A representative of the Museum of Our Industrial Heritage in Greenfield, Massachusetts, arguing for the continuing relevance of the Wiley and Russell Dam, puts it this way:

I need to stress a point emotionally. This stuff is like David and Goliath. With us being David. The forces that [supported dam removal] were well organized, well funded. There is a bulldozer of this philosophy, the avoidance of an open debate, and the idea of our resources. We had to take our private lives and set aside and battle this thing [dam removal]. ${ }^{39}$

A similar perspective was put forward by members of the SRPA regarding a rationale for working so vehemently to retain the Upper Bondsville Dam. Responding to a question about the perception of an eastern bias in the state (where the Boston metropolitan region tends to dominate the state's political economy), one participant commented, "Well, you know... and frankly it still is [a bias], I mean... they don't know we exist out here, and maybe that's good,

\footnotetext{
${ }^{39}$ Interview, Museum of our Industrial Heritage, Greenfield, Mass., Sept. 23, 2014
} 
you know [laughter]. ${ }^{40}$ This perspective was intensified and took on the language of class conflict as the plan for removal of the dam unfurled, promoted by a local land trust that was perceived as controlled by local elites. At the first public meeting, held in 2009, residents of the neighborhood adjacent to the Swift River upstream of the dam felt blindsided and reacted with anger to the general tone of the presentation regarding the dam's potential removal.

... you knew, you knew from the attitude, you knew from the posturing, that their game plan was to take this down... The other thing that stood out... was arrogance. And pompousness. And boy there's nothing that irritates me more than that. From day one to the end, when they walked out, we were the country bumpkins that didn't have a collective brain between all of us. ${ }^{41}$

Eventually, the SRPA launched a two-year, focused grassroots campaign employing a range of tactics (e.g., social media, floats in local parades, tabling at town events, lobbying state legislators) that culminated in the dam's survival.

The Swift River case underscores the intensely personal nature of dam removal politics. Nowhere is this more evident than in the aforementioned case of efforts to remove a dam in Swanton, VT located on the Missisquoi River just 12 kilometers upstream of where it empties into Lake Champlain. The Swanton Dam has been long targeted for removal by several stakeholders on the argument it would open up critical habitat for lake sturgeon and walleye populations. The most vocal of the removal proponents include Lake Champlain International (LCI), a Colchester, VT-based NGO. Wayne LaRoche, a current affiliate of LCI and a local resident, stated, "I'm characterizing it [Swanton Dam removal] as the best fishery habitat restoration potential project in the state. ${ }^{42}$ LaRoche, however, is in an interesting position in terms of the micropolitics of removal. As former Vermont Commissioner of Fish \& Wildlife, he occupied a highly visible governing position and used this to press for removal of the dam. However, as resident of a township near Swanton, he also had, and continues to have, daily interactions with neighbors and townsfolk adamantly opposed to removal, one of whom is his second cousin. As he explained in our conversation, "It's just like the Red Sox and Yankees. It literally is a family affair and so you don't want to sue your cousin, when you know he's already

\footnotetext{
${ }^{40}$ Interview, Swift River Preservation Association, Belchertown, Mass., April 24, 2014

${ }^{41}$ Ibid.

${ }^{42}$ Interview, July 17, 2013
} 
just being hard-headed." ${ }^{43}$ The micropolitics swirling around potential removal of the Swanton Dam extended into local town governance as well. As the idea of removing dam was being floated during public meetings and in the local media, an advocate of historic preservation and powerful opinion maker emerged as one of the main opponents of removal. A staff member from LCI maintains that this person used his influence to dampen any latent enthusiasm amongst town residents for removing the dam.

Then you have the [District Court] judge who's the president of the Historical Society who's also the zoning administrator, who, everyone in town who wants the dam out tells us [LCI and pro-removal forces], confides, 'I support that you're doing it, keep doing it, but you can't tell anybody that I do, 'cause I need a permit next summer for my deck., 44

Of the 50 or so dam removal initiatives that have stalled or are completely halted in New England over the past decade, all, albeit unique in the specific trajectory of opposition and political strategies, exhibit a micropolitics characterized by personal interlocution within the community and suspicion of the motivations of outsiders. As we have shown, the micropolitics of dam removal are fuelled by a combination of attachment to a historically significant landscape and a particular understanding of that landscape as natural or preferable. However, it would be remiss to ignore how the micropolitics of dam removal are connected to nature-society discourses and practices occurring at broader scalar configurations. For example, both state and Federal actors play important roles in originating, funding, and regulating dam removal in New England and are enrolled in the complex environmental politics of dam removal.

\section{Conclusion}

During an interview with a fisheries biologist who has been active in the 14-year effort to remove the East Burke Dam, we asked why the process was so prolonged. He answered, "probably because of me." He went on to explain that while he was from Burke, he was not from East Burke. In other words, he was an outsider, and when they "went into town and said we are going to remove the dam, ${ }^{45}$ it galvanized (or maybe even created) the opposition. This anecdote speaks volumes about how micropolitics become bound up with contestations over local histories and identities, and how this affects who gets to define and speak for nature.

\footnotetext{
${ }^{43}$ Ibid.

${ }^{44}$ Interview, Lake Champlain International, July 17, 2013

${ }^{45}$ Interview, Vermont Fish and Wildlife, Oct. 3, 2013
} 
Because political ecology focuses attention on complex cultural dynamics and divergent interpretations of nature-issues that have traditionally fallen outside the concerns of ecological restoration - it is a crucial lens for understanding the environmental politics that characterize interventions into highly altered ecosystems. Our investigation of dam removals in New England reveals how both regionalizing and politicizing ecological restoration initiatives advance understanding of these conflicts. In this region, where thousands of dams have transformed water- and landscape, historical and geographical contingencies shape and alter conflicts over dam removal as environmental restoration in important ways. Moreover, there is no single variable or factor that can explain these conflicts. Powerful attachments to dammed landscapes, uncertainty associated with the ecological impacts of dam removal, and dynamic micropolitics all come together to help explain how environmental conflicts play out. In trying to explain contested dam removals, the material and cultural landscape of this region matters.

This brings us back to our question about what conflicts over removals reveal about the politics of ecological restoration in highly altered landscapes. To a certain extent, every dam removal case is unique, but clear themes emerge across our cases. What is evident from our research is the need to take seriously how aesthetics, sense of place, history, and environmental knowledge come together to influence perceptions of and attachment to the sorts of highly humanized landscapes that characterize the Anthropocene. It may be that, in some dam removal cases, there is simply resistance to the change that the intervention brings. But, for the most part, our research suggests that the reasons for opposition are much more complex. An important dimension of this complexity is the fact that cultures, identities, and communities are dynamic. In multiple removal cases, peoples' ideas changed over the course of many years, as they rethought and re-defined their relationship to a dam and the adjacent landscape, ultimately changing their position regarding a proposed removal.

Moreover, as our research reveals, very often resistance is equally a response to being told what to do by outsiders as it is to dam removal itself. At the end of our interview with opponents of the removal of the Wiley and Russell Dam, one of the interviewees noted (in response to our question about whether their success in saving the dam was a temporary one): 
That's all we were asking for! Was a fair evaluation. And that's undergoing. So you know, if the dam ultimately comes out, you know, I'll be disappointed, but, you know ... there are realities that have to be accepted. ${ }^{46}$

This relates to one of our central claims: the need to re-think environmental politics in ways that highlight its occurrence outside of formal institutional channels typified by environmental legislation, organized social movements (including the work of NGOs), and even specific campaigns. Dam removal and similar examples where micropolitics play a central role build on (and problematize) more grandiose claims of environmental politics as merely a kind of subpolitics (see Beck, 1997). At its heart, our efforts here are designed to shed light on the "ordinary environmental politics" that are keyed more to people's daily engagements with their landscapes and responses to interventions that are perceived as threats to those landscapes (Tsing, 2005, p. 112). Focusing on these contestations of landscapes' materiality and meaning reveals the often hidden, quotidian political ecologies at work in specific locales that we argue are important elements of contemporary environmental conflicts. Contestations over dam removal suggest that questions about what, exactly, constitutes a desirable ecosystem and, concomitantly, a place to live and engage with, will increasingly characterize environmental politics in the Anthropocene. Moreover, there is practical value in unpacking and understanding these types of conflicts. Ecological restoration in general, and dam removal in particular, are expensive and time-consuming endeavors. As the cases cited above demonstrate, failure to anticipate and understand opposition to removal often leads to failed efforts, which arguably wastes time and money, while creating tension within communities and between stakeholders.

\footnotetext{
${ }^{46}$ Interview, Museum of our Industrial Heritage, Greenfield, MA, Sept. 23, 2014
} 


\section{References}

Abrams, J. \& Gosnell, H. (2012). The politics of marginality in Wallowa County, Oregon: Contesting the production of landscapes. Journal of Rural Studies, 28, 30-37.

American Rivers. (2002). The Ecology of Dam Removal: A Summary of Benefit and Impacts. Washington, DC: American Rivers.

American Rivers. (2010). 60 dams removed to restore rivers in 2010. Unpublished document. Retrieved from: http://www.americanrivers.org/assets/pdfs/dam-removaldocs/2010-dam-removals.pdf

American Rivers. (2013). Whittenton Dam Removal Begins in Taunton. Retrieved from: http://www.americanrivers.org/newsroom/press-releases/whittenton-dam-removalbegins-in-taunton/

Baker, S., Eckerberg, K. \& Zachrisson, A. (2014). Political science and ecological restoration. Environmental Politics, 23(3), 509-524.

Batterbury, S. (2001). Landscapes of diversity: a local political ecology of livelihood diversification in south-western Niger. Cultural Geographies, 8(4), 437-464.

Beck, U. (1997). Subpolitics ecology and the disintegration of institutional power. Organization \& Environment, 10(1), 52-65.

Bennett, J. (2010). Vibrant Matter: A Political Ecology of Things. Duke University Press.

Bernhardt, E.S., Palmer, M., Allan, J.D., Alexander, G., Barnas, K., Brooks, S., Carr, J., Clayton, S., Dahm, C., Follstad-Shah, J., others. (2005). Synthesizing U.S. river restoration efforts. Science, 308, 636-637.

Bernhardt, E.S., Sudduth, E.B., Palmer, M.A., Allan, J.D., Meyer, J.L., Alexander, G., Follastad-Shah, J., Hassett, B., Jenkinson, R., Lave, R., others. (2007). Restoring rivers one reach at a time: results from a survey of US river restoration practitioners. Restoration Ecology, 15, 482-493.

Braun, B. (2015). Futures: imagining socioecological transformation — an introduction, Annals of the Association of American Geographers, 105(2), 239-243.

Busquets, Joan. (2011). The deconstruction and construction of a major metropolitan space in Seoul. In Busquets, J. (ed.) Deconstruction/Construction: The Cheonggyecheon Restoration Project in Seoul, pp. 1-18. Cambridge, MA: Harvard University Graduate School of Design.

Buck, C. D. (2013). Post-environmentalism: an internal critique. Environmental Politics, 22(6), 883-900. 
Buizer, M. \& Turnhout, E. (2011). Text, talk, things, and the subpolitics of performing place. Geoforum, 42, 530-538.

Castree, N. (2014). The Anthropocene and geography III: Future directions. Geography Compass, 8(7), 464-476.

Campbell, L.M. \& Meletis, C.A. (2011). Agreement on water and a watered-down agreement: The political ecology of contested coastal development in Down East, North Carolina. Journal of Rural Studies, 27(3), 308-321.

Chaloupka, W. (2008). The environmentalist:'what is to be done?'. Environmental Politics, 17(2), 237-253.

Crutzen, P. J. \& Stoermer, E. F. (2000). 'The Anthropocene'. Global Change Newsletter, 41, 1718.

Curtis, K.E., Renshaw, C.E., Magilligan, F.J., \& Dade, W.B. (2010). Temporal and spatial scales of geomorphic adjustments to reduced competency following flow regulation in bedload-dominated systems. Geomorphology, 118, 105-117.

Demeritt, D. (2002). What is the 'social construction of nature'? A typology and sympathetic critique. Progress in Human Geography, 26(6), 767-790.

Devine-Wright, P. (2009). Rethinking NIMBYism: The role of place attachment and place identity in explaining place-protective action. Journal of Community \& Applied Social Psychology, 19(6), 426-441.

Downs, P.W., \& Kondolf, G.M. (2002). Post-project appraisals in adaptive management of river channel restoration. Environmental Management, 29, 477-496.

Dufour, S. \& Piegay, H. (2009). From the myth of a lost paradise to targeted river restoration: forget natural references and focus on human benefits. River Research and Application, $25,568-581$.

Dunn, K. (2000). Interviewing. In Hay, I. (ed.) Qualitative Research Methods in Human Geography, pp. 50-82. Oxford, UK: Oxford University Press.

Duncan, J., \& Duncan, N. (2004). Landscapes of Privilege: The Politics of the Aesthetic in an American Suburb. New York: Routledge.

Eden, S., Tunstall, S., \& Tapsell, S. (2000). Translating nature: river restoration as nature-culture. Environment and Planning D: Society and Space, 18(2), 257-273.

Eden, S. \& Tunstall, S. (2006). Ecological versus social restoration? How urban river restoration challenges but also fails to challenge the science policy nexus in the United Kingdom. Environment and Planning C: Government and Policy, 24, 661-680. 
Emery, S., Perks, M. \& Bracken, L. (2013). Negotiating river restoration: The role of divergent reframing in environmental decision-making. Geoforum, 47, 167-177.

Failing, L., Gregory, R. \& Higgins, P. (2012). Science, uncertainty, and values in ecological restoration: a case study in structured decision-making and adaptive management. Restoration Ecology, 21(4), 422-430.

Forsyth, T. (2003). Critical Political Ecology. London: Routledge.

Gobster, P., Nassauer, J., Daniel, T., \& Fry, G. (2007). The shared landscape: what does aesthetics have to do with ecology? Landscape Ecology 22, 959-972.

Gosnell, H. \& Kelly, E. and Kelly. (2010). Peace on the river? Social-ecological restoration and large dam removal in the Klamath basin, USA. Water Alternatives 3(2).

Grant, G.E., \& Lewis, S.L. (2015). The remains of the dam: what have we learned from 15 years of US dam removals?, In Lollino, G., Arattano, M., Rinaldi, M., Giustolisi, O., Marechal, J.C., Grant, G.E. (eds.) Engineering Geology for Society and Territory, vol. 3, pp. 31-35, Springer.

Gross, M. (2008). Return of the wolf: Ecological restoration and the deliberate inclusion of the unexpected. Environmental Politics, 17(1), 115-120.

Hall, C.J., Jordaan, A., \& Frisk, M.G. (2011). The historic influence of dams on diadromous fish habitat with a focus on river herring and hydrologic longitudinal connectivity. Landscape Ecology, 26, 95-107.

Helford, R. M. (2000). Constructing nature as constructing science: Expertise, activist science, and public conflict in the Chicago wilderness, pp. 119-142. In Gobster, P. H. and Hull, R. B. (eds) Restoring Nature: Perspectives from the Social Sciences and Humanities, Washington, DC: Island Press.

Hobbs, R., Hallett, L., Ehrlich, P., \& Mooney, H. (2011). Intervention ecology: applying ecological science in the twenty-first century. Bioscience, 61(6), 442-450.

Holen, D. (2004). The Atna' and the political ecology of the Copper River fishery, Alaska Arctic Anthropology 41(1), 58-70.

Holifield, R. \& Schuelke, N. (2015). The place and time of the political in urban political ecology: contested imaginations of a river's future. Annals of the Association of American Geographers 105, 294-303.

Horowitz, L.S. (2008). "It's up to the clan to protect": cultural heritage and the micropolitical ecology of conservation in New Caledonia. The Social Science Journal, 45(2), 258-278. 
Hurley, P. T. \& Halfacre, A. C. (2011). Dodging alligators, rattlesnakes, and backyard docks: A political ecology of sweetgrass basket-making and conservation in the South Carolina Lowcountry, USA. GeoJournal, 76(4), 383-399.

Hunter, L. C. (1979). A History of Industrial Power in the United States 1780-1930: Volume One: Waterpower in the Century of the Steam Engine. Eleutherian Mills-Hagley Foundation.

Jahnig, S.C., Lorenz, A.W., Hering, D., Antons, C., Sundermann, A., Jedicke, E. \& Haase, P. (2011). River restoration success: a question of perception. Ecological Applications, 21(6), 2007-2015.

Johnson, S \& Graber, B. (2002) Enlisting the social sciences in decisions about dam removal BioScience, 52(8), 731-738.

Jørgensen, D. (2014). Rethinking rewilding. Geoforum, 65, 482-488.

Jorgensen, D. \& Renofalt, B. (2012). Damned if you do, dammed if you don't: debates on dam removal in the Swedish Media. Ecology and Society, 18(1), 18.

Lave, R. (2008). The Rosgen Wars and the Shifting Political Economy of Expertise. Unpublished doctoral thesis, University of California, Berkeley.

Lave, R. (2012a). Bridging Political Ecology and STS: A Field Analysis of the Rosgen Wars. Annals of the Association of American Geographers, 102(2), 366-38.

Lave, R. (2012b). Fields and Streams: Stream Restoration, Neoliberalism and the Future of Environmental Science. Athens: The University of Georgia Press.

Lave, R. (2014). Freedom and constraint: Generative expectations in the US stream restoration field Geoforum, 52, 236-244.

Lave, R., Doyle, M. \& Robertson, M. (2010). Privatizing stream restoration in the US. Social Studies of Science 40, 677-703.

Law, J., \& McSweeney, K. (2013). Looking under the canopy: Rural smallholders and forest recovery in Appalachian Ohio. Geoforum, 44, 182-192.

Lord, W.B. (1979). Conflict in federal water-resource planning. Water Resources Bulletin, 15, 1226-1235.

Lorimer, J., \& Driessen, C. (2014). Wild experiments at the Oostvaardersplassen: rethinking environmentalism in the Anthropocene. Transactions of the Institute of British Geographers, 39(2), 169-181. 
Magilligan, F.J., Nislow, K.H., Graber, B., Sneddon C., Fox, C., \& Martin, E. (2014). River restoration by dam removal: assessing riverine re-connectivity across New England, American Geophysical Union Poster EP43A-3542, Annual Meeting, San Francisco.

Magilligan, F., Nislow, K., Graber, B., Chipman, J., Sneddon, C. \& Fox, C. (In Review). River restoration by dam removal: assessing riverine re-connectivity and watershed resilience at a regional scale. Elementa: Science of the Anthropocene.

Mansfield, B., Biermann, C., McSweeney, K., Law, J., Gallemore, C., Horner, L. \& Munroe, D.K. (2015). Environmental Politics After Nature: Conflicting Socioecological Futures. Annals of the Association of American Geographers, 105, 284-293.

McCarthy, J. (2002). First world political ecology: lessons from the Wise Use movement. Environment and Planning A, 34, 1281-1302.

McCarthy, J. (2001). States of nature and environmental enclosures in the American West, pp. 117-146. In Peluso, N.L. \& Watts, M. (eds) Violent Environments, Ithaca, NY: Cornell University Press.

Michaud, K., Carlisle, J. E., \& Smith, E. R. (2008). Nimbyism vs. environmentalism in attitudes toward energy development. Environmental Politics, 17(1), 20-39.

Moore, D. S. (1998). Clear waters and muddied histories: Environmental history and the politics of community in Zimbabwe's eastern highlands. Journal of Southern African Studies, 24(2), 377-403.

Neumann, R. (1992). Political ecology of wildlife conservation in the Mt. Meru area of Northeast Tanzania. Land Degradation \& Rehabilitation, 3(2), 85-98.

Neumann, R. (2009). Political ecology II: theorizing the region. Progress in Human Geography, 34(3), 368-374.

Neumann, R. (2011). Political ecology III: theorizing landscape. Progress in Human Geography, $35(6), 843-850$.

Nilsson, C. \& Berggren, K. (2000). Alterations of Riparian Ecosystems Caused by River Regulation. BioScience, 50(9), 783-792.

NOAA. (2012). Making way for the nation's migrating fish. Retrieved from: http://www.habitat.noaa.gov/ourwork/fishpassage.html (accessed 7 January 2012).

Ogden, L. (2008). The Everglades Ecosystem and the Politics of Nature. American Anthropologist,110(1), 21-32. 
Ogden, L., Heynen, N., Oslender, U., West, P., Kassam, K. A., \& Robbins, P. (2013). Global assemblages, resilience, and Earth Stewardship in the Anthropocene. Frontiers in Ecology and the Environment, 11(7), 341-347.

Opperman, J.J., Royte, J., Banks, J., Rose Day, L., \& Apse, C. (2011). The Penobscot River, Maine, USA: a Basin-Scale Approach to Balancing Power Generation and Ecosystem Restoration. Ecology and Society, 16.

Palmer, M.A. \& Bernhardt, E.S. (2006). Hydroecology and river restoration: Ripe for research and synthesis. Water Resources Research, 42(3), 1-4.

Palmer, M.A., Bernhardt, E.S., Allan, J.D., Lake, P.S., Alexander, G., Brooks, S., Carr, J., Clayton, S., Dahm, C.N., Follstad Shah, J., Galat, D.L., Loss, S.G., Goodwin, P., Hart, D.D., Hassett, B., Jenkinson, R., Kondolf, G.M., Lave, R., Meyer, J.L., O’Donnell, T.K., Pagano, L., \& Sudduth, E. (2005). Standards for ecologically successful river restoration: Ecological success in river restoration. Journal of Applied Ecology, 42, 208-217.

Pincetl, S., Jonas, A. E., \& Sullivan, J. (2011). Political ecology and habitat conservation for endangered species planning in Southern California: Region, places, and ecological governance. Geoforum, 42(4), 427-438.

Prudham, W. S. (2012). Knock on Wood: Nature as Commodity in Douglas-fir Country. New York: Routledge.

Reed, C. (2011). The ecological (and urbanistic) agency of infrastructure. In Busquets, J. (ed.) Deconstruction/Construction: The Cheonggyecheon Restoration Project in Seoul, pp. 3546. Cambridge, MA: Harvard University Graduate School of Design.

Rhoads, B.L., Wilson, D., Urban, M. \& Herricks, E.E. (1999). Interaction between scientists and nonscientists in community-based watershed management: Emergence of the concept of stream naturalization. Environmental Management 24, 297-308.

Rikoon, J. S. (2006). Wild horses and the political ecology of nature restoration in the Missouri Ozarks. Geoforum, 37, 200-211.

Robbins, P. (2006). The politics of barstool biology: Environmental knowledge and power in greater Northern Yellowstone Geoforum, 37, 185-199.

Robbins, P. (2007). Lawn People: How Grasses. Weeds, and Chemicals Make Us Who We Are. Philadelphia: Temple University Press.

Robbins, P. \& Sharp, J. (2003). Producing and consuming chemicals: The moral economy of the American lawn. Economic Geography, 79(4), 425-451. 
Robertson, M. (2000). No net loss: Wetland restoration and the incomplete capitalization of nature. Antipode, 32(4), 463-493.

Robertson, M. (2006). The nature that capital can see: science, state, and market in the commodification of ecosystem services. Environment and Planning D: Society and Space, 24, 367-387.

Rootes, C. (2007). Acting locally: The character, contexts and significance of local environmental mobilisations. Environmental Politics, 16(5), 722-741.

Ryan, R.L. (2006). Comparing the attitudes of local residents, planners, and developers about preserving rural character in New England. Landscape and Urban Planning, 75, 522.

Salmond, A., Tadaki, M. \& Gregory, T. (2014). Enacting new freshwater geographies: Te Awaroa and the transformative imagination. New Zealand Geographer, 70, 47-55.

Sanborn, A. (2009). Oyster River Dam in Jeopardy. Retrieved from: http://fosters.com/apps/pbcs.dll/article?AID=/20090217/GJNEWS_01/702179926/1/FosNEWS02

Saunders, R., Hachey, M.A., \& Fay, C.W. (2006). Maine's diadromous fish community: past, present, and implications for Atlantic salmon recovery. Fisheries 31, 537-547.

Seastedt, T., Hobbs, R. \& Suding, K. (2008). Management of novel ecosystems: are novel approaches required? Frontiers in Ecology and the Environment, 6, 1-8.

Society for Ecological Restoration (SER). (2004). The SER International Primer on Ecological Restoration. Retrieved from: http://www.ser.org/docs/default-documentlibrary/english.pdf.

Small, M \& Doyle, M. (2012). Historical perspectives on river restoration design in the USA. Progress in Physical Geography, 36(2), 138-153.

Spegman, A. (2012). Two sides to dam issue; panel wants more time. Retrieved from: http://www.sentinelsource.com/news/local/sides-to-dam-issue-pan.

Spink, A., Hillman, M., Fryirs, K., Brierley, G., \& Lloyd, K. (2010). Has river rehabilitation begun? Social perspectives from the Upper Hunter catchment, New South Wales, Australia. Geoforum, 41(3), 399-409.

Swift River Preservation Association (SRPA)(2011). Save the Bondsville Dam and Swift River Petition. Retrieved from: https://www.facebook.com/Save-the-Bondsville-Dam-and-SwiftRiver-150990508271281/ 
Swift River Preservation Association. (2012). Frequently asked questions. Retrieved from: http://swiftriverpreservationassociation.org/

Steffen, W., Crutzen, P. J., \& McNeill, J. R. (2007). The Anthropocene: Are Humans Now Overwhelming the Great Forces of Nature. AMBIO: A Journal of the Human Environment, 36(8), 614-621.

Steinberg, T. (1991). Nature Incorporated: Industrialization and the Waters of New England. Amherst, MA: University of Amherst Press.

Suding, K.N. (2011). Toward an era of restoration in ecology: successes, failures, and opportunities ahead. Annual Review of Ecology, Evolution and Systematics, 42, 465-487.

Tadaki, M., Brierley, G. \& Cullum, C. (2014). River classification: theory, practice, politics WIREs Water 1, 349-367.

Tadaki, M. \& Sinner, J. (2014). Measure, model, optimise: Understanding reductionist concepts of value in freshwater governance. Geoforum 51, 140-151.

Thompson. L. (2008). Dam removal push sparks Swanton hydropower study. St. Albans Messenger, Oct. 14.

Thompson, D.M. (2013). The Quest for the Golden Trout. Lebanon, NH: University Press of New England.

Trigger, D., Mulcock, J., Gaynor, A., \& Toussaint, Y. (2008). Ecological restoration, cultural preferences and the negotiation of 'nativeness' in Australia. Geoforum, 39(3), 1273-1283.

Tsing, A. L. (2005). Friction: An Ethnography of Global Connection. Princeton University Press.

Urban, M.A., 2005. Values and ethical beliefs regarding agricultural drainage in central Illinois, USA. Society \& Natural Resources 18, 173-189.

Van der Horst, D. (2007). NIMBY or not? Exploring the relevance of location and the politics of voiced opinions in renewable energy siting controversies. Energy policy, 35(5), 2705-2714.

Varady, R., Hankins, K.B., Kaus, A., Young, E. \& Merideth, R. (2001). . . . to the Sea of Cortes: nature, water, culture, and livelihood in the Lower Colorado River basin and delta--an overview of issues, policies, and approaches to environmental restoration. Journal of Arid Environments, 49, 195-209. 
Vickers, D. (2004). Those dammed shad: Would the river fisheries of New England have survived in the absence of industrialization? The William and Mary Quarterly, 61(4), 685-712.

Vorkinn, M., \& Riese, H. (2001). Environmental concern in a local context: the significance of place attachment. Environment and Behaviour, 33, 249-263.

Walker, P. (2003). Reconsidering 'regional' political ecologies: toward a political ecology of the rural American West. Progress in Human Geography, 27(1), 7-24.

Walker, P. \& Fortmann, L. (2003). Whose landscape? A political ecology of the 'exurban' Sierra. Cultural Geographies, 10, 469-491.

Walter, R.C. \& Merritts, D.J. (2008). Natural streams and the legacy of water-powered mills. Science, 319, 299-304.

Walton, Brett. (2015) Pace of U.S. Dam Removals Accelerates. Circle of Blue. Retrieved from: http://www.circleofblue.org/waternews/2015/world/pace-u-s-dam-removals-accelerates/

Weng, Yen-Chu. (2015). Contrasting visions of science in ecological restoration: Expert-lay dynamics between professional practitioners and volunteers. Geoforum, 65, 134-145.

Whisenant, S. (2011). The Society for Ecological Restoration. Ecological Restoration, 29(3), 207-208.

Wohl, E., Lane, S.N. \& Wilcox, A.C. (2015). The science and practice of river restoration. Water Resources Research, 51 (8), 5974-5997.

Zweig, C. \& Kitchens, W. (2010). The Semiglades: The Collision of Restoration, Social Values, and the Ecosystem Concept. Restoration Ecology, 18(2), 138-142. 